\title{
Effect of macroalgae and yeast culture on body performance, blood metabolites, ruminal fermentation and digestibility coefficients of Ossimi lambs
}

\author{
Abu El-Kassim M. A. ${ }^{a^{*}}$, Abdou S. G. ${ }^{\text {a }}$, Hassan E. H. ${ }^{\mathrm{a}}$, Abdullah M. A. M. ${ }^{\mathrm{b}}$ \\ ${ }^{a}$ Animal Production Department, Faculty of Agriculture, Al-Azhar University, Assiut, Egypt \\ ${ }^{b}$ Animal Production Department, Faculty of Agriculture, Assiut University, Assiut, Egypt
}

\begin{abstract}
This study was carried out to evaluate the effect of macroalgae (Halimeda opuntia) and yeast culture (saccharomyces cerevisiae) as feed additives on body performance, some blood plasma constituents, some rumen parameters and nutrients digestibility of growing lambs. Fifteen Ossimi lambs 5-6 months old and 25.51 $\pm 2 \mathrm{~kg}$ live body weight were randomly divided into three equal groups (5 animals each). Control group (CON) was fed the basal diet and other two treatment groups were fed the same basal diet, supplemented with either $1 \%$ macroalgae powder (ALG) or $1 \%$ yeast culture (YC). Lambs were weighed to determine performance of growing lambs and adjusted the requirement. Blood samples were collected monthly from all animals before morning feeding. Rumen samples were collected to determine ruminal $\mathrm{pH}$ values, ammonia-N concentration and total volatile fatty acids (TVFAs) concentration. The digestibility trials were carried out to evaluate nutrients digestibility of the different experimental rations. Final body weight and total gain not affected by treatments. Lambs of ALG group had the worst feed conversion ratio compared with YC and $\mathrm{CON}$ group. Ruminal $\mathrm{pH}$, ammonia-N concentration and TVFAs were not affected by treatments. Dietary yeast or macroalgae increased $(\mathrm{P}<0.05)$ blood plasma total protein and albumin concentrations, while decreased $(\mathrm{P}<0.05)$ plasma urea $-\mathrm{N}$ concentration compared with those of control animals. Dietary macroalgae increased $(\mathrm{P}<0.05) \mathrm{DM}, \mathrm{OM}, \mathrm{CP}$, $\mathrm{CF}$ and NFE digestibility compared with YC and CON groups. In conclusion, macroalgae and yeast culture as feed additives may have a beneficial effect on nutrients digestibility and blood metabolites of Ossimi sheep male.
\end{abstract}

Keywords: macroalgae, Halimeda opuntia, Saccharomyces cerevisiae, rumen fermentation. 


\section{Introduction}

Algae are organisms that can range in size, from microscopic microalgae to large macroalgae. The most common algae are red, brown and green algae. Macroalgae do not require fertilizers, pesticides, or freshwater (Chojnacka et al., 2012). Macroalgae can be used to improve basal feed quality because they are rich in primary metabolites essential to metabolic function as minerals, vitamins, proteins, lipids and polysaccharides that (MacArtain et al., 2007; Marın et al., 2009; Rjiba Ktita et al., 2019). Macroalgae are one of the richest sources of calcium ( $7 \%$ of the dry weight, Singh et al., 2016). They are also rich source of other minerals like sodium, potassium, magnesium, chlorine, sulfur, phosphorus, iodine, iron, zinc, copper, selenium and molybdenum (Archer et al., 2008; Holdt and Kraan, 2011; Rey-Crespo et al., 2014; Ventura and Castañón, 1998). High mineral content makes it a potential additive to animal feedstuffs for replacing a part or whole of the mineral supplementation (Singh et al., 2017). Macroalgae have anti-bacterial, anti-viral, antioxidant, and anti-inflammatory properties that enhance animal health and function (Bach et al., 2008) because, they contain many biologically active compounds such as fucoidan, betaine, and glucans (Archer et al., 2008; Holdt and Kraan, 2011), which enhance animal's immunity and carcass quality (Singh et al., 2017). Yeast culture (Saccharomyces cerevisiae) one of the most common probiotics in ruminants (Raghebian et al., 2016). Yeast culture has displayed positive impact on the growth and viability of rumen microflora through encouraging cellulolytic bacterial growth within the ruminal environment (Ovinge et al., 2018; Swyers et al., 2014). Live yeast consumes free oxygen in the rumen with respiration, so provides an anaerobic environment that proper for rumen metabolic function (Newbold et al., 1996). Inclusion of yeast culture to ruminant diets has improved fiber digestibility (Dawson et al., 1990), increased protozoal count (Singh et al., 2008). The aim of this study to evaluate the effect of macroalgae (Halimeda opuntia) as natural mineral source and yeast culture (Saccharomyces cerevisiae) as feed additives on body performance, ruminal fermentation, and digestibility of Ossimi lambs.

\section{Materials and methods}

This study was conducted at the Research Farm of Animal Production Department, Faculty of Agriculture, Al-Azhar University, Assiut, Egypt. The laboratory measurements conducted at the Animal Production Department laboratory at the same faculty to evaluate the influence of macroalgae (Halimeda opuntia) and yeast culture (Saccharomyces cerevisiae) as feed additives on body performance, ruminal fermentation, and digestibility of Ossimi lambs. The study was divided into two experiments. The first experiment was growing trial while, the second one was digestibility trial.

\subsection{Growing trial}

\subsubsection{Animals management and rations}

Growing trial was carried out using fifteen 
Ossimi lambs 5-6 months old and about $25.51 \pm 2 \mathrm{~kg}$ body weight, animals were randomly distributed into three groups, each with five lambs, the trial lasted for 120 days. The lambs in group one was considered as control (CON) which fed total mixed ration which consisting of 65 $\%$ concentrate mixture and 35\% wheat straw. Concentrate mixture contain $42 \%$ yellow corn, $15 \%$ soybean meal, $30 \%$ wheat bran, $10 \%$ undecorticated cottonseeds meal, $2 \%$ limestone and $1 \%$ salt. The second (ALG) and third (YC) groups received the same basal diet supplemented with either1\% macroalgae (Halimeda opuntia) or $1 \%$ yeast culture (Saccharomyces cerevisiae) of total mixed ration, respectively. Ingredients and chemical composition of control and supplemented rations are presented in Table (1).

Table (1): Ingredients and chemical composition of control and macroalgae and yeast culture-treated rations.

\begin{tabular}{|l|l|l|l|}
\hline \multirow{2}{*}{ Item } & \multicolumn{3}{l}{ Treatment* } \\
\cline { 2 - 4 } & CON & ALG & YC \\
\hline Yellow corn & 27.3 & 27.3 & 27.3 \\
\hline Soybean meal & 9.75 & 9.75 & 9.75 \\
\hline Wheat bran & 19.5 & 19.5 & 19.5 \\
\hline Undecorticated Cottonseeds meal & 6.5 & 6.5 & 6.5 \\
\hline Wheat straw & 35 & 35 & 35 \\
\hline Macroalge powder (Halimeda opuntia) & - & 1 & - \\
\hline Yeast culture (Saccharomyces cerevisiae) & - & - & 1 \\
\hline Limestone & 1.3 & 1.3 & 1.3 \\
\hline Salt & 0.325 & 0.325 & 0.325 \\
\hline Minerals & 0.325 & 0.325 & 0.325 \\
\hline Chemical composition & \multicolumn{3}{|l}{} \\
\hline Dry Matter \% & 92.12 & 92.12 & 92.12 \\
\hline Organic matter \% & 90.97 & 90.58 & 90.81 \\
\hline Ash \% & 9.03 & 9.42 & 9.19 \\
\hline Crude protein \% & 14.55 & 14.73 & 14.85 \\
\hline Crude fiber \% & 18.08 & 17.80 & 17.72 \\
\hline Ether extract \% & 2.99 & 3.26 & 3.18 \\
\hline NFE \% & 55.34 & 54.79 & 55.06 \\
\hline
\end{tabular}

$*^{*} \mathrm{CON}=$ basal diet, consisted of $65 \%$ concentrate mixture and $35 \%$ wheat straw; ALG = basal diet supplemented with $1 \%$ macroalgae (Halimeda opuntia) powder and $\mathrm{YC}=$ basal diet supplemented with $1 \%$ yeast culture (Saccharomyces cerevisiae) of total mixed ration.

Ration was fed to the treated group as follow: First group, (CON) lambs fed basal diet (total mixed ration). Second group, (ALG). Lambs fed basal diet supplemented by $1 \%$ of macroalgae (Halimeda opuntia). Third group, (YC). lambs fed basal diet supplemented by $1 \%$ of yeast culture. The rations were formulated to satisfy sheep requirements according to NRC omitted (1985). Daily ration (total mixed ration) was divided into two equal parts and offered at 8.00 a.m. and 3.00 p.m. daily. Fresh water was available all the day. The chemical analysis of feed samples and residuals was carried out according to methods of 
AOAC (1990). Nitrogen-free extract and organic matter were calculated by difference.

\subsubsection{Blood sampling and analysis}

At the begging of the experiment and every month during the experimental period about $10 \mathrm{ml}$ of blood were collected from the jugular vein from each animal within each group before morning feeding. Blood samples were directly collected into clean dried glass culture tubes with EDTA (Ethylene Diamine Tetra Acetic Acid) which work as anticoagulant then centrifuged at 4000 rpm for 20 minutes; blood plasma was separated into a clean dried glass vial and stored at $-20^{\circ} \mathrm{C}$ till chemical analysis. Plasma metabolites: total protein, albumin, (globulin calculation was obtained as the difference between total protein and albumin concentration), cholesterol, and urea were done according to the methods described by Gornall et al. (1949). Webster (1974), Allain et al. (1974) and Tabacco et al. (1979), respectively.

\subsubsection{Rumen liquor}

At the end of growing trial, rumen samples were collected from lambs using a stomach tube. Samples were taken $2 \mathrm{hrs}$ after morning feeding. Rumen liquor samples were filtrated through 3 layers of cheese cloth. Rumen $\mathrm{pH}$ values were immediately determined after collection of rumen liquor using digital $\mathrm{pH}$ meter (Beckman, model 45, USA). Strained rumen liquor was stored in blastic bottles $(100 \mathrm{ml})$ with few drops of toluene and paraffin oil just to cover the surface and stored at a deep freeze $\left(-18^{\circ} \mathrm{C}\right)$ till chemical analysis. Ruminal ammonia-N concentration was determined according to AOAC (1990) and total VFA's concentration was determined according to Warner (1964).

\subsection{Digestibility trials}

The digestibility trials were carried out to evaluate nutrients digestibility of the different experimental rations.

\subsubsection{Animals and rations}

Three mature rams about $50 \pm 2.5 \mathrm{~kg}$ body weight from each group were randomly selected for the digestion trial. Animals were individually placed in metabolic cages for 21 days, the first 14 days as a preliminary period followed by 7 days as a collection period. Daily rations offered and residuals were recorded every day. Faeces were collected daily and $10 \%$ of total weight was dried at $60^{\circ} \mathrm{C}$ for $24 \mathrm{hrs}$ then it was mixed and ground for the chemical analysis.

\subsubsection{Chemical Analysis and digestion coefficients calculated}

Samples of feed ingredient and faeces were analyzed for dry matter, ash, crude protein, crud fiber and ether extract according to methods of AOAC (1990). Nitrogen-free extract and organic matter were calculated by difference. The 
apparent digestion coefficients of of time blood sampling, (BA) ij nutrients were calculated by expressing =interaction between time and treatments the difference between the content of nutrients in both consumed feed and faeces as a percentage of its intake.

\subsection{Statistical analysis} and meijk $=$ the errors related to individual observation. The significance differences among treatment means were tested by (Duncan`s multiple range test 1995).

Data were statistically analyzed using general linear model (G.L.M) procedure of S.A.S (2002). For body weight change, nutrients digestibility, rumen liquor parameters and feed conversion ratio the following model was used, $Y_{i j}=\mu+T_{i}+$ $\mathrm{E}_{\mathrm{ij}}$, Where, $\mathrm{Yij}=$ experimental observation, $\mu=$ general mean, $\mathrm{Ti}=$ the effect of treatment, $\quad \mathrm{i}=\mathrm{T} 1, \mathrm{~T} 2$ and $\mathrm{T} 3$ and $\mathrm{Eij}=$ the errors related to individual observation. The blood parameters were analyzed according to the following statistical model:

$Y i j k=\mu+T i+B j+(B A) i j+e i j k$

Where, Yijk = experimental observations, $\mu=$ general mean, $\mathrm{Ti}=$ the effect of treatment, $\mathrm{i}=\mathrm{T} 1, \mathrm{~T} 2$ and $\mathrm{T} 3, \mathrm{Bj}=$ the effect

\section{Results and Discussion}

\subsection{Growing trial}

\subsection{Performance of growing lambs}

The effect of treatments on performance of growing lambs is presented in Table (2). The data revealed that the final body weight and total gain were similar in all groups, that means there was no significant difference among groups. However, dietary yeast tended to increase daily gain compared to other treatment groups. Feed conversion ratio was significantly $(\mathrm{P}<0.05)$ improved in favor of $\mathrm{YC}$ and control groups as compared with ALG group.

Table (2): Effect of dietary dietary macroalgae and yeast culture on performance of growing lambs.

\begin{tabular}{|l|l|l|l|l|}
\hline \multirow{2}{*}{ Item } & \multicolumn{3}{l}{ Treatment* } \\
\cline { 2 - 5 } & CON & ALG & YC & SEM \\
\hline Initial body weight $(\mathrm{kg})$ & 25.88 & 25.51 & 25.15 & 0.303 \\
\hline Final body weight $(\mathrm{kg})$ & 48.01 & 47.54 & 48.21 & 0.317 \\
\hline Total feed intake $(\mathrm{kg})$ & 151.74 & 148.15 & 156.58 & \\
\hline Total gain kg & 22.13 & 22.03 & 23.06 & 0.243 \\
\hline Duration of the experiment & 120 days \\
\hline Daily gain $(\mathrm{g} / \mathrm{d})$ & 184.38 & 183.58 & 192.14 & 1.012 \\
\hline TDN & $66.56^{\mathrm{b}}$ & $70.25^{\mathrm{a}}$ & $67.11^{\mathrm{b}}$ & 0.426 \\
\hline Feed conversion $(\mathrm{kg}$ TDN /kg gain) & $4.575^{\mathrm{b}}$ & $4.726^{\mathrm{a}}$ & $4.571^{\mathrm{b}}$ & 0.065 \\
\hline
\end{tabular}

a,b,c Means with the same letter within rows are not significantly different. SEM= standard error of means, $* \mathrm{CON}=$ basal diet, consisted of $65 \%$ concentrate mixture and $35 \%$ wheat straw; ALG = basal diet supplemented with $1 \%$ macroalgae (Halimeda opuntia) powder and $\mathrm{YC}=$ basal diet supplemented with $1 \%$ yeast culture (Saccharomyces cerevisiae) of total mixed ration. 
These results are in agreement with the results obtained by Bach et al. (2008), found that dietary macroalgae (Ascophyllum nodosum) at level of $10 \mathrm{gm} / \mathrm{kg}$ diet had no effect on body weight and average daily gain in steers. Also, Samara et al. (2013) and Abdoun et al. (2014) found that dietary macroalgae had no effect on body weight and average daily gain of growing lams fed diet supplemented with green macroalgae Ulva lactuca at levels of $3 \%$ and $5 \%$. Also, Macedo et al. (2006) found that yeast culture had no significant effect on body weight and average daily gain of growing lambs. Also, Soren et al. (2012), Pienaar et al. (2012), and Hamdon and Farghaly (2016) found that yeast culture at levels of $1.5 \%, 0.5 \%$ and $1 \%$ had no effect on body weight and average daily gain in growing lambs.

\subsubsection{Rumen fermentation}

The effect of treatments on rumen liquor $\mathrm{pH}$, Ammonia- $\mathrm{N}$ concentrations and total volatile fatty acids concentration are presented in Table (3). Results indicated that there were no significant differences among groups in rumen liquor $\mathrm{pH}$ values, ammonia-N and total volatile fatty acids concentration. These results are in agreement with many author's results i.e. Tripathi and Karim (2011) indicated that rumen ammonia-N concentration and total volatile fatty acids concentration were not affected by yeast culture supplementation at level $1 \mathrm{gm} / \mathrm{kg}$ live weight of growing lamb. Also, Soren et al. (2012) found yeast culture (at level 1.5\%) had no effect on rumen fluid $\mathrm{pH}$ values and total volatile fatty acids concentration. These results are in agreement with the result obtained by Zhou et al. (2018) they found that brown macroalgae (Ascophyllum nodosum) supplementation at levels of $1 \%$ and $3 \%$ had no effect on total VFA, $\mathrm{NH}_{3}-\mathrm{N}$ concentrations and $\mathrm{pH}$ of rumen liquor. Similarly, Ead and Maklad (2011) found that ammonia-N concentration and total volatile fatty Acids of rumen liquor were not affected by supplementing fattening Friesian steers ' ration by $0.4 \%$ and $0.9 \%$ of macroalgae.

Table (3): Effect of dietary algae and yeast culture on rumen fermentation of Ossimi lambs.

\begin{tabular}{|l|l|l|l|l|}
\hline \multirow{2}{*}{ Item } & \multicolumn{2}{|l|}{ Treatment* } & \multirow{2}{*}{ SEM } \\
\cline { 2 - 4 } & CON & ALG & YC & \\
\hline $\mathrm{pH}$ values & 6.770 & 6.783 & 6.500 & 0.052 \\
\hline Total volatile fatty acids (meq/100ml) & 11.00 & 11.33 & 11.67 & 0.179 \\
\hline Ammonia-N (mg/dl) & 17.46 & 18.66 & 17.58 & 0.361 \\
\hline
\end{tabular}

*CON=basal diet, consisted of $65 \%$ concentrate mixture and $35 \%$ wheat straw; ALG $=$ basal diet supplemented with $1 \%$ macroalgae (Halimeda opuntia) powder and $\mathrm{YC}=$ basal diet supplemented with $1 \%$ yeast culture (Saccharomyces cerevisiae) of total mixed ration. 


\subsubsection{Blood constituents}

The effect of treatments on blood plasma constituents are presented in Table (4). The data reveled that plasma total protein and albumin concentrations increased significantly in treated groups compared with control one with no significant difference between treated groups (ALG and YC) whereas, there were no significant difference among groups in plasma globulin, albumin: globulin ratio and cholesterol concentrations. On the other hand, plasma urea concentration decreased significantly in treated groups as compared with control one with no significant difference between ALG and YC groups.

Table (4): Effect of dietary macroalgae and yeast culture on some blood plasma conistitutes of lambs.

\begin{tabular}{|c|c|c|c|c|c|c|c|c|c|c|c|c|c|}
\hline Item & \multicolumn{4}{|c|}{ Treatments* } & \multicolumn{6}{|c|}{ Sampling time } & \multicolumn{3}{|c|}{ Significance } \\
\hline Albumin & $2.88^{\mathrm{B}}$ & $2.99^{\mathrm{A}}$ & $3.00^{\mathrm{A}}$ & 0.034 & $2.75^{\mathrm{d}}$ & $2.68^{d}$ & $2.92^{\mathrm{c}}$ & $3.07^{\mathrm{b}}$ & $3.37^{\mathrm{a}}$ & 0.034 & $* *$ & **** & $* *$ \\
\hline AL/GL & 0.97 & 0.95 & 0.98 & 0.019 & $0.93^{\mathrm{b}}$ & $0.83^{\mathrm{c}}$ & $0.90^{\mathrm{b}}$ & $0.96^{\mathrm{b}}$ & $1.20^{\mathrm{a}}$ & 0.022 & Ns & *** & $* *$ \\
\hline Cholesterol & 85.85 & 85.51 & 85.74 & 0.583 & $92.12^{\mathrm{a}}$ & $79.95^{\mathrm{e}}$ & $82.16^{\mathrm{d}}$ & $84.12^{\mathrm{c}}$ & $90.15^{\mathrm{b}}$ & 0.483 & Ns & *** & Ns \\
\hline Urea & $42.99^{\mathrm{A}}$ & $38.23^{\mathrm{B}}$ & $37.45^{\mathrm{B}}$ & 0.574 & $45.03^{\mathrm{a}}$ & $41.55^{\mathrm{b}}$ & $39.43^{c}$ & $35.20^{\mathrm{d}}$ & $36.56^{d}$ & 0.506 & $* * *$ & $* * *$ & $* *$ \\
\hline
\end{tabular}

$\mathrm{A}, \mathrm{B}, \mathrm{C}, \mathrm{a}, \mathrm{b}, \mathrm{c}, \mathrm{d}, \mathrm{e}$ Means with the same letter within rows are not significantly different. SEM= standard error of means $* *=$ $\mathrm{P}<0.01, * * *=\mathrm{P}<0.0001, \mathrm{NS}=$ non-significant $\mathrm{D} \times \mathrm{T}=$ interaction between diets $(\mathrm{D})$ and sampling times $(\mathrm{T}), * \mathrm{CON}=\mathrm{basal}$ diet, consisted of $65 \%$ concentrate mixture and $35 \%$ wheat straw; $\mathrm{ALG}=$ basal diet supplemented with $1 \%$ macroalgae (Halimeda opuntia) powder and YC = basal diet supplemented with $1 \%$ yeast culture (Saccharomyces cerevisiae) of total mixed ration.

The sampling time affected significantly $(\mathrm{p}>0.01)$ plasma total protein albumin, globulin, albumin: globulin ratio, cholesterol and urea concentration. The increase of blood total protein and albumin in treated groups may be due to the addition of macroalgae and yeast culture stimulate the development of intestinal microflora resulting in improved feed digestion and utilization of feed nutrients (Karatzia et al., 2012) or may be due to macroalgae supplementation can enhance immune function and overall animal health in lambs (Saker $e t$ al., 2004).

\subsection{Digestibility trial}

Inclusion of macroalgae powder by $1 \%$ in
ALG group improved $(\mathrm{P}<0.05)$ nutrients digestibility as compared with $\mathrm{CON}$ and YC groups (table 5). It could be noticed that, there were improved $(\mathrm{P}<0.05)$ in $\mathrm{DM}, \mathrm{OM}, \mathrm{CP}, \mathrm{CF}$ and NFE digestibility of ALG group compared to those of other two groups. The improvement in nutrients digestibility in ALG group may be due to that macroalgae are rich in primary metabolites essential to metabolic function as minerals, vitamins, proteins, lipids and polysaccharides that can be used to improve basal feed quality (MacArtain et al., 2007; Marín et al., 2009). Also, such improvement, may be due to that macroalgae increased bacterial number in the rumen which resulted in improvement of nutrients digestibility. 
Table (5): Effect of dietary macroalgae and yeast culture on nutrients digestibility coefficients.

\begin{tabular}{|l|l|l|l|l|}
\hline \multirow{2}{*}{ Item } & \multicolumn{2}{|l|}{ Treatment } & \multirow{2}{*}{ SEM } \\
\cline { 2 - 4 } & CON & ALG & YC & \\
\hline Dry matter \% & $63.69^{\mathrm{b}}$ & $67.72^{\mathrm{a}}$ & $64.87^{\mathrm{b}}$ & 0.440 \\
\hline Organic matter \% & $68.37^{\mathrm{b}}$ & $72.44^{\mathrm{a}}$ & $68.86^{\mathrm{b}}$ & 0.485 \\
\hline Crude protein \% & $65.31^{\mathrm{c}}$ & $71.66^{\mathrm{a}}$ & $69.22^{\mathrm{b}}$ & 0.652 \\
\hline Crude fiber \% & $54.05^{\mathrm{b}}$ & $56.91^{\mathrm{a}}$ & $52.40^{\mathrm{b}}$ & 0.615 \\
\hline Either extract \% & 78.36 & 80.12 & 78.14 & 0.581 \\
\hline Nitrogen free Extract \% & $73.29^{\mathrm{b}}$ & $77.07^{\mathrm{a}}$ & $73.35^{\mathrm{b}}$ & 0.480 \\
\hline
\end{tabular}

a,b,c Means with the same letter within rows are not significantly different. SEM= standard error of means, *CON=basal diet, consisted of $65 \%$ concentrate mixture and $35 \%$ wheat straw; ALG = basal diet supplemented with $1 \%$ macroalgae (Halimeda opuntia) powder and $\mathrm{YC}=$ basal diet supplemented with $1 \%$ yeast culture (saccharomyces cerevisiae) of total mixed ration.

These results are in agreement with the results obtained by Rjiba-Ktita et al. (2019), they found that using of seaweeds (Ruppia sp.) in the concentrate ration of Barbarine male lambs increased $(\mathrm{P}<0.05)$ crude fiber digestibility. Similarly, Ead and Maklad (2011) found that the digestion coefficients of OM, NFE, ADF and cellulose were slightly higher when fattening Friesian steers fed ration supplemented with seaweeds. In contrast our results, some studies found no effect by adding seaweeds on any digestion coefficient i.e. Singh et al. (2017) found no effect of macroalgae (Sargassum wightii) on digestion coefficient of Sahiwal cows. Also, Zhou et al. (2018) found that brown seaweed had no effect on the digestibility coefficients of various nutrients in ram. This difference may be due to the difference in the percentage used for macroalgae.

\section{Conclusion}

It could be concluded that macroalgae and yeast culture as feed additives may have a beneficial effect on blood metabolites and digestion coefficients of Ossimi lambs.

\section{References}

Abdoun, K. A., Okab, A. B. A., ElWaziry, M., Samara, E. M. and AlHaidary, A. A. (2014), "Dietary supplementation of seaweed (Ulva lactuca) to alleviate the impact of heat stress in growing lambs", Pakistan Veterinary Journal, Vol. 34 No 1, pp.108-111.

Allain, C. C., Poon, L. S., Chan, C. S. G., Richmond, W. and Fu, P. C. (1974), "Enzymatic determination of total serum cholesterol", Clinical chemistry, Vol. 20 No. 4, pp. 470475 .

AOAC (1990), Official methods of analysis, $15^{\text {th }}$ Edition, The Association of Official Analytical Chemists, Arlington, Virginia, USA.

Archer, G. S., Friend, T. H., Caldwell, D., Ameiss, K., Krawczel, P. D., Iacono, 
C., Keen, H. and Martin. T. (2008), "Impacts of feeding several components of the seaweed Ascophyllum nodosum on transported lambs", Animal feed science and technology, Vol. 140 No. 3-4, pp. 258-271.

Bach, S. J., Wang, Y. and McAllister, T. A. (2008), "Effect of feeding sundried seaweed (Ascophyllum nodosum) on fecal shedding of Escherichia coli O157:H7 by feedlot cattle and on growth performance of lambs", Animal Feed Science and Technology, Vol. 142 No. 1-2, PP. 17-32.

Chojnacka, K., A.Saeid, Z. Witkowska, and L Tuhy. (2012), "Biologically active compounds in seaweed extracts-the prospects for the application", The Open Conference Proceedings Journal, Vol. 3 No. 1, pp. 20-28.

Dawson, K. A., Newman, K. E. and Boling, J. A. (1990), "Effects of microbial supplements containing yeast and lactobacilli on roughage fed ruminal microbial activities", Journal of Animal Science, Vol. 68 No. 10, pp. 3392-3398.

Duncan, D. B. (1955), "Multiple Range and Multiple F Tests", International Biometric Society, Vol. 11 No. 1, pp. $1-42$.

Ead, H., and Maklad, E. (2011), "Effects of Seaweed Supplementation to Fattening Friesian Steers Rations on: 1-the Nutritive Value and Rumen
Fermentation", Journal of Animal and Poultry Production, Vol. 2 No. 11, pp. 471-483.

Gornall, A. G., Bardawill, C. J. and David, M. M. (1949), "Determination of serum proteins by means of the biuret reaction", Journal of Biological Chemistry, Vol. 177 No. 2, pp. 751766.

Hamdon, H. A., and Farghaly, M. M. (2016), "Improving growth performance and carcass characteristics of lambs as a result caring management via dietary yeast", Egypt Journal of Animal Production, Vol. 53 No. 2, pp. 103110.

Holdt, S. L., and Kraan, S. (2011), "Bioactive compounds in seaweed: Functional food applications and legislation", Journal of Applied Phycology, Vol. 23 No. 3, pp. 543597.

Karatzia, M., Christaki, E., Bonos, E., Karatzias, C. and Florou-Paneri, P. (2012), "The influence of dietary Ascophyllum nodosum on haematologic parameters of dairy cows", Italian Journal of Animal Science, Vol. 11 No. 2, pp. 169-173.

MacArtain, P., Gill, C. I., Brooks, R. M., Campbell, R. and Rowland, I. R. (2007), "Nutritional value of edible seaweeds", Nutrition reviews, Vol. 65 No. 12, pp. 535-543.

Macedo, R., Arredondo, V. and Beauregard, J. (2006), "Influence of 
yeast culture on productive performance of intensively fattened Pelibuey lambs in Colima, México", Avances en Investigación Agropecuaria, Vol. 10 No. 3, pp. 6980.

Marín, A., Casas-Valdez, M., Carrillo, S., Hernández, H., Monroy, A., Sanginés, L. and Pérez-Gil, F. (2009), "The marine algae sargassum spp. (Sargassaceae) as feed for sheep in tropical and subtropical regions", Revista de Biología Tropical, Vol. 57 No. 4, pp. 1271-1281.

Newbold, C. J., Wallace, R. J. and Mcintosh, F. M. (1996), "Mode of action of the yeast Saccharomyces cerevisiae as a feed additive for ruminants", British Journal of Nutrition, Vol. 76 No. 2, pp. 249261.

Ovinge, L. A., Sarturi, J. O., Galyean, M. L., Ballou, M. A., Trojan, S. J., Campanili, P. R. B., Alrumaih, A. A. and Pellarin, L. A. (2018), "Effects of a live yeast in natural-program finishing feedlot diets on growth performance, digestibility, carcass characteristics, and feeding behavior", Journal of Animal Science, Vol. 96 No. 2, pp. 684-693.

Pienaar, G. H., Einkamerer, O. B., Van Der Merwe, H. J., Hugo, A. and Scholtz, G. D. J. (2012), "The effects of an active live yeast product on the growth performance of finishing lambs", South African Journal of Animal Science, Vol. 42 No. 5, pp. 464-468.
Raghebian, M., Babaei Yazdi, A. Dabiri, N., Hajimohammadi, A., Hatami, P., Raghebian, A., Shomeyzi, J. and Bahrani, M. J. (2016), "Effect of different levels of live yeast in a high concentrate diet on performance, blood constituents and immune system status of Zandi Lambs", Iranian Journal of Applied Animal Science, Vol. 6 No. 4, pp. 830-840.

Rey-Crespo, F., López-Alonso, M. and Miranda, M. (2014), "The use of seaweed from the Galician coast as a mineral supplement in organic dairy cattle", Animal, Vol. 8 No. 4, pp. 580-586

Rjiba-Ktita, S., Chermiti, A., Valdés, C. and López, S. (2019), "Digestibility, nitrogen balance and weight gain in sheep fed with diets supplemented with different seaweeds", Journal of Applied Phycology, Vol. 31 No. 5, pp. 3255-3263.

Saker, K. E., Fike, J. H., Veit, H. and Ward, D. L. (2004), "Brown seaweed- (TascoTM) treated conserved forage enhances antioxidant status and immune function in heat-stressed wether lambs", Journal of animal physiology and animal nutrition, Vol. 88 No. 34, pp. 122-130.

Samara, E. M., Okab, A. B., Abdoun, K. A., El-Waziry, A. M. and AlHaidary, A. A. (2013), "Subsequent influences of feeding intact green seaweed Ulva lactuca to growing lambs on the seminal and testicular characteristics in rams", Journal of 
animal science, Vol. 91 No. 12, pp. 5654-5667.

SAS Institute (2009), "Using JMP Student Edition for Windows and Macintosh", The User's Guide to Statistics with JMP Student Edition, SAS Institute, Cary, North Carolina.

Singh, B. K., Chopra, R. C., Rai, S. N., Verma, M. P. and Mohanta, R. K. (2016), "Effect of feeding seaweed as mineral source on mineral metabolism, blood and milk mineral profile in cows", Proceedings of the National Academy of Sciences, India Section B: Biological Sciences, Vol. 86 No.1, pp. 89-95.

Singh, B. K., Chopra, R. C., Rai, S. N., Verma, M. P. and Mohanta, R. K. (2017), "Nutritional Evaluation of Seaweed on Nutrient Digestibility, Nitrogen Balance, Milk Production and Composition in Sahiwal Cows", Proceedings of the National Academy of Sciences, India Section B: Biological Sciences, Vol. 87 No. 2, pp. 437-443.

Singh, G., Kulkarni, S. and Singh, R. (2008), "Effect of Saccharomyces cerevisiae (Yea-sacc ${ }^{1026}$ ) supplementation on rumen profi le in buffaloes", Indian Journal of Animal Sciences, Vol. 78 No. 2, pp. 172-174.

Soren, N. M., Tripathi, M. K., Bhatt, R. S. and Karim, S. A. (2012), "Effect of yeast supplementation on the growth performance of Malpura lambs", Tropical Animal Health and Production, Vol. 45 No. 2, pp. 547-
554.

Swyers, K. L., Wagner, J. J., Dorton, K. L. and Archibeque. S. L. (2014), "Evaluation of Saccharomyces cerevisiae fermentation product as an alternative to monensin on growth performance cost of gain, and carcass characteristics of heavy weight yearling beef steers", Journal of Animal Science, Vol. 92 No. 6, pp. 2538-2545.

Tabacco, A., Meiattini, F., Moda, E. and Tarli, P. (1979), "Simplified enzymic/colorimetric serum urea nitrogen determination", Clinical Chemistry, Vol. 25 No. 2, pp. 336337.

Tripathi, M. K. and Karim, S. A. (2011), "Effect of yeast cultures supplementation on live weight change, rumen fermentation, ciliate protozoa population, microbial hydrolytic enzymes status and slaughtering performance of growing lamb", Livestock Science, Vol. 135 No. 1, pp. 17-25.

Ventura, M. R., and Castañón, J. I. R. (1998), "The nutritive value of seaweed (Ulva lactuca) for goats", Small Ruminant Research, Vol. 29 No. 3, pp. 325-327.

Warner, A. C. (1964), "Production of volatile fatty acids in the rumen: methods of measurement", Nutrition Abstracts and Reviews, Vol. 34 No. 2, pp. 339-352.

Webster, D. (1974), "A study of the 
interaction of bromocresol green with isolated serum globulin fractions", Clinica Chimica Acta, Vol. 53 No. 1, pp. 109-115.

Zhou, M., Hünerberg, M., Chen, Y., Reuter, T., McAllister, T. A., Evans, F., Critchley, A. T. and Guan, L. L. (2018), "Air-dried brown seaweed, Ascophyllum nodosum, alters the rumen microbiome in a manner that changes rumen fermentation profiles and lowers the prevalence of foodborne pathogens", MSphere, Vol. 3 No. 1, pp. 1-18. 